\title{
Solitary Fibrous Tumor of the Tentorium: A Case Report
}

\section{Tentorium Soliter Fibröz Tümörü: Bir Olgu Sunumu}

\author{
Jacob Paul ALAPATT ${ }^{1}$, Ajaya Kumar A ${ }^{1}$, Aparna GOVINDAN² , Rajeev MP ${ }^{1}$, Radhakrishnan $\mathrm{M}^{1}$ \\ ${ }^{1}$ Government Medical College, Department of Neurosurgery, Kerala, India \\ ${ }^{2}$ National Institute of Mental Health and Neurosciences, Department of Neuropathology, Bangalore, India
}

Correspondence address: Aparna GOVINDAN / E-mail: aparnabyju@yahoo.co.in

\begin{abstract}
The authors describe the clinical and pathological features of a solitary fibrous tumor of the tentorium, a rare location for the tumor in the CNS. A 52-year-old lady presented to the neurosurgical services with headache of four months and vertigo of one and a half months duration. On examination, she had left-sided cerebellar signs and bilateral papilloedema. Cranial MR imaging showed an enhancing tumor based on the left tentorium. Clinical impression was a meningioma. The patient underwent left suboccipital craniectomy. The tumor was firm and vascular, extending above the tent through a defect. Total excision was achieved. The correct diagnosis of solitary fibrous tumor could be made only by histopathology. Solitary fibrous tumors of the tentorium, though rare, should be included in the differential diagnosis of dural based masses.
\end{abstract}

KEYWORDS: Solitary fibrous tumor, Tentorium, Meningioma, CD 34, Hemangiopericytoma, Vimentin

öz

Yazarlar MSS'de tümör için nadir bir konum olan tentoriuumda soliter fibröz tümörün klinik ve patolojik özelliklerini tanımlamaktadır. 52 yaşında bir kadın hasta beyin cerrahisi polikliniğine dört aydır başağrısı ve bir buçuk aydır başdönmesiyle başvurdu. Muayenede sol tarafta serebellar bulgular ve bilateral papilla ödemi mevcuttu. Kraniyal MR görüntüleme sol tentorium temelli kontrast tutan bir tümör gösterdi. Klinik izlenim menenjiyomdu. Hastaya suboksipital kraniyektomi yapıldı. Tümör sert ve vaskülerdi ve bir defekt yoluyla çadırın üzerine uzanmaktaydı. Total eksizyon yapıldı. Soliter fibröz tümörün doğru tanısı sadece histopatoloji ile konabildi. Tentorium soliter fibröz tümörleri nadir olmalarına rağmen dura kökenli kitlelerin ayırıcı tanısında dikkate alınmalıdır.

ANAHTAR SÖZCÜKLER: Soliter fibröz tümör, Tentorium, Menenjiyom, CD 34, Hemanjiyoperisitom, Vimentin

\section{INTRODUCTION}

Solitary fibrous tumors are uncommon benign mesenchymal neoplasms initially described by Klemperer and Rabin in 1931(9) along the mesothelium-lined membranes, most commonly the pleura. They have now been described in various other locations as well. Involvement of the CNS is rare and has been attributed to the paucity of true connective tissue elements. An origin from dural fibroblasts has been proposed (3). This lesion affecting mainly adults may involve both the cranial and spinal meninges, and may show invasion of CNS parenchyma, nerve roots or the skull base (14). Approximately a hundred and odd cases have been reported previously at various sites within the CNS. Involvement of the tentorium cerebelli is rarely recorded $(2,5,6,15)$. We report a case of tentorial solitary fibrous tumor in a 52-yearold lady who presented with headache, vertigo and leftsided cerebellar signs. MR Imaging revealed a left tentorial tumor. The clinical diagnosis considered was meningioma on imaging and peroperatively. Histopathological examination revealed a solitary fibrous tumor, an indolent benign lesion.

\section{CASE REPORT}

A 52-year-old female patient presented to the neurosurgical services with a history of headache of four months and vertigo of one and a half months duration. On examination, she had left-sided cerebellar signs. Bilateral papilloedema was noted on ocular fundoscopy. Routine haematological and biochemical investigations were within normal limits. Cranial CT scan showed a hyperdense enhancing lesion based on the left tentorium and extending above the tent. On MRI the lesion was isointense on T1W images with hypointense periphery (Figure $1 \mathrm{~A}$ ) and hypointense on $\mathrm{T} 2 \mathrm{~W}$ images (Figure 1B) with heterogenous enhancement on contrast (Figure 1C). MR angiography demonstrated a feeder from the artery of Bernasconi. The clinical and radiological features were highly suggestive of a meningioma. The patient underwent left suboccipital craniectomy. A large $6 \times 6 \mathrm{~cm}$ firm vascular tumor was seen extending above the tent through a defect. The feeding artery was coagulated and the tumor was resected totally detaching from the tentorial edge. The postoperative period was uneventful. The patient is asymptomatic at two 

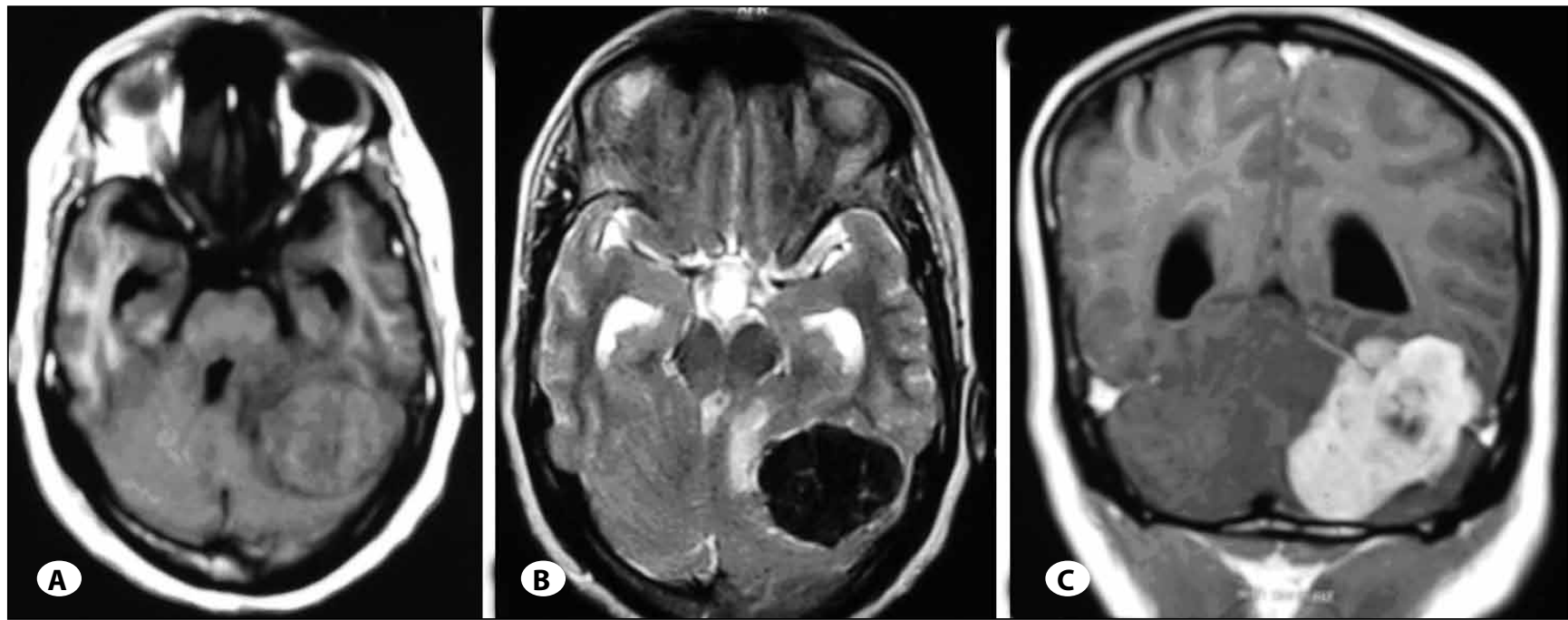

Figure 1: MRI - Left tentorial lesion, isointense on T1W with hypointense periphery (A). Hypointense on T2W images (B).Tumor based on the tent and extending above it showing heterogenous enhancement on contrast (C).
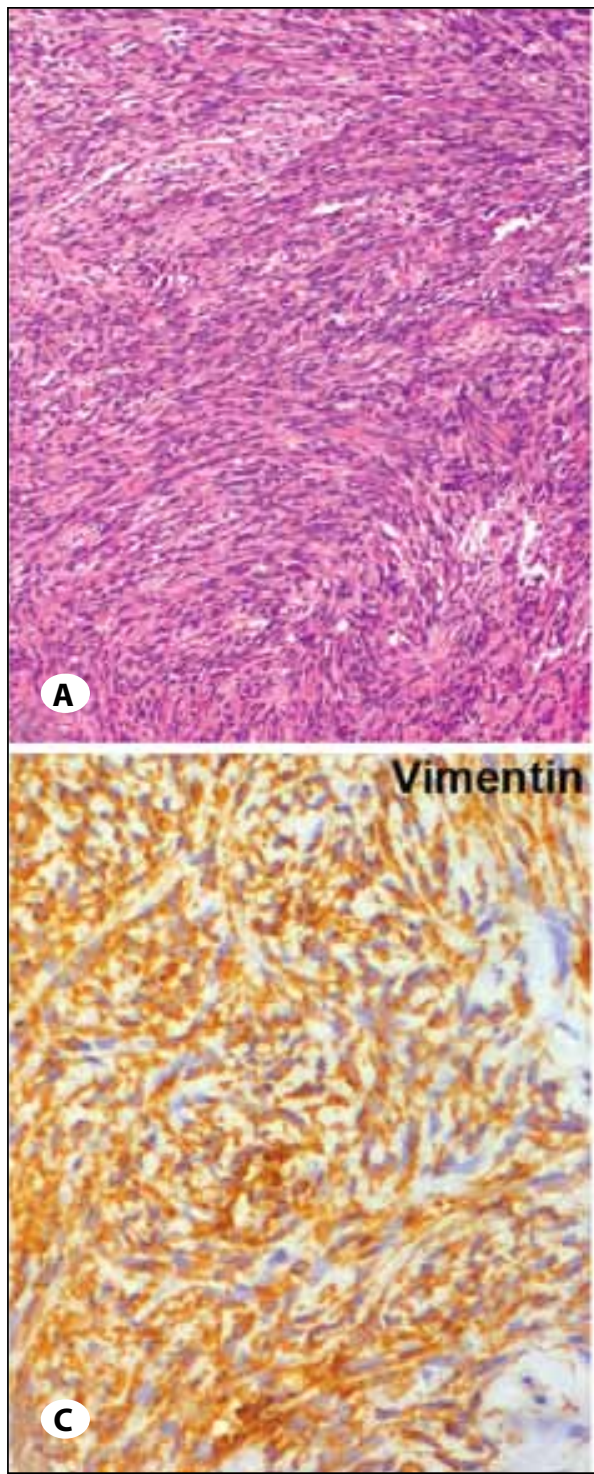

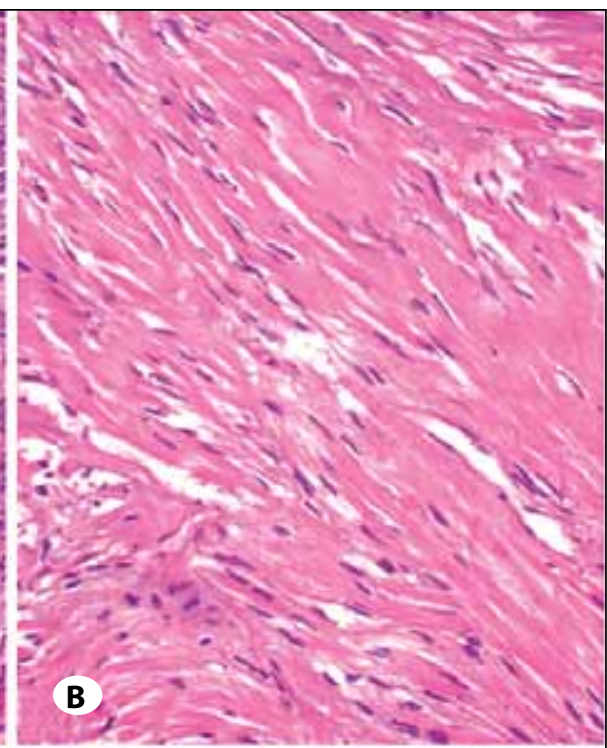

CD 34

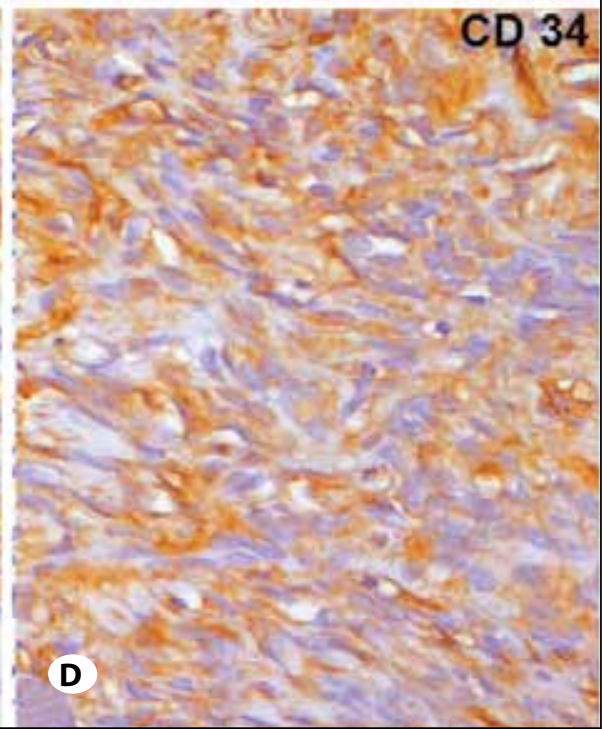

Figure 2: Cellular areas showing interlacing fascicles of spindle shaped cells (A). Paucicellular areas showing dense collagen separating the cells (B). Tumor cells showing strong immunoreactivity for vimentin (C) and CD 34 (D). A- HEX80, B-HEX160, C-VIMENTIN X 320, D- CD34 X 320. 
years follow up with no evidence of tumor recurrence on CT scan.

Histopathological examination showed a partly circumscribed neoplasm composed of cellular and paucicellular areas. In the cellular areas, the tumor showed interlacing fascicles of spindle-shaped cells with moderate amount of cytoplasm and oval to elongated nuclei exhibiting variable pleomorphism (Figure 2A). One small cellular nodule in the middle of the mass was seen composed of closely packed cells with hyperchromatic oval nuclei. No mitotic activity was noted. In the paucicellular areas, dense bands of collagen were seen separating the cells (Figure 2B). The stroma was myxoid in areas and thin vascular channels were present. On immunohistochemistry, the spindle shaped tumor cells were strongly labelled with antibody to vimentin (Figure $2 \mathrm{C}$ ) and CD 34 (Figure 2D). The MIB-1 labeling index was low, even in the cellular nodule.

\section{DISCUSSION}

Solitary fibrous tumors are rare neoplasms that develop from membranes like the pleura, peritoneum and meninges, the pleura being the commonest site. Other sites reported include the paranasal sinuses, thyroid, larynx, sublingual gland, pelvis, ovary, cervix, kidney, tongue, skin and cauda equina.

In the central nervous system they form dural-based masses mimicking meningiomas (21). The usual sites are clinoid process (1), orbit, sellar- and parasellar area (10), middle cranial fossa (1), cerebellopontine angle $(2,17)$, lateral ventricle (18) and the falx cerebri $(8,20)$. In the lateral ventricle the favoured sites are the body and trigone. Tentorial location is uncommon. Only eleven cases have been repoted to date (5). Clinical manifestations of the tumors depends on the anatomical site involved and include exophthalmos (1), loss of vision (10), hemiparesis (1), hearing loss (17), facial palsy (17), headache $(8,10)$, seizures and papilloedema (18). Imaging characteristics resemble those of meningiomas. On CT imaging the features are varied and the tumors are discrete extra axial masses, lobulated, solid, with peritumoral cyst or bone invasion. On MR imaging they have mixed intensity, enhance on contrast and dural thickening may be present. On angiography delayed tumor blush and/or dysplastic dilatation of tumor vessels may be seen (22). Vascular supply can be traced to the Internal Carotid Artery $(1,10)$, the Middle Meningeal Artery (10) or other arteries in the vicinity.

Peroperatively these tumors are firm, fibrous and vascular (18). Sometimes there may be a poor plane between the brain and the tumor (8). Vascularity and subsequent hemorrhage may limit resection (10), although gross total resection is possible in most of the cases. Ventricular tumors may be attached to the choroid plexus (18).

Histopathologically they are mostly benign tumors resembling fibrous meningioma or hemangiopericytoma (19) although rare cases of malignant solitary fibrous tumor are on record $(13,21)$. Spindle cells arranged in long fascicles with intervening eosinophilic collagenous stroma and irregular vascular lumina are seen (8). On immunohistochemistry, the tumor cells express CD 34, vimentin and antiapoptotic marker bcl-2 and are negative for epithelial membrane antigen, thus distinguishing them from meningiomas. These tumors have low mitotic index by MIB-1 labelling. Some of the tumors previously reported as fibrous meningiomas or hemangiopericytomas have turned out to be solitary fibrous tumors on review (19). According to the recent WHO Classification of Tumors of Soft Tissue and Bone, most lesions formerly considered as hemangiopericytomas show no evidence of pericytic differentiation and instead are fibroblastic in nature thus forming a morphological continuum with solitary fibrous tumor. This may pertain to meningeal hemangiopericytomas as well (4).

Histogenesis of solitary fibrous tumors is still controversial. Stout and Sano (in 1942 and 1950 respectively) suggested a mesothelial origin of this neoplasm based on in vitro cell culture studies. Later studies based on ultrastructure resulted in the same conclusion. A submesothelial origin was proposed by Dalton et al. in 1979. Burrig et al observed mesenchymal undifferentiated cells, immature fibroblasts and mature fibroblasts on biopsies of the tumors pointing to a mesenchymal origin. Immunohistochemical studies also do not support a mesothelial origin (7). In the CNS the origin of the tumor may be from CD34 positive dural fibroblasts in the meningeal portion of the dura (3).

Total excision is the treatment of choice. Radiotherapy is administered if the excision is subtotal or partial $(8,10,12,23)$. The chemotherapeutic agent Toremifene can also be administered if the proliferation rate is high (10). Recurrence and also malignant transformation have been reported in meningeal solitary fibrous tumors $(6,11,16,20,21)$. Hakan et $\mathrm{al}$, in their review, have come across a higher rate of recurrence in tentorial tumors that they have attributed to the incompleteness of resection (5). Long-term follow up of these cases is therefore essential to detect recurrence.

\section{REFERENCES}

1. Ahn JY, Shim JY, Yang WI, Kim TS: Meningeal solitary fibrous tumor as an unusual cause of exophthalmos. Neurosurgery 48(6):1362-1366, 2001

2. Carneiro SS, Scheithauer BW, Nascimento AG, Hirose T, Davis $\mathrm{DH}$ : Solitary fibrous tumor of the meninges: A lesion distinct from fibrous meningioma. A clinicopathologic and immunohistochemical study. Am J Clin Pathol 106(2): 217-224, 1996

3. Cummings TJ, Burchette JL, McLendon RE: CD 34 and dural fibroblasts: The relationship to solitary fibrous tumor and meningioma. Acta Neuropathologica 102(4):349-354, 2001

4. Guillou L, Fletcher JA, Fletcher CDM, Mandahl N: Extrapleural solitary fibrous tumor and haemangiopericytoma. In: Christopher D. M. Fletcher, K. Krishnan Unni, Fredrik Mertens, (eds), Pathology and Genetics of Tumours of Soft Tissue and Bone. Lyon: IARC Press, 2002: 86-90 
5. Hakan T, Turk CC, Aker FV: Tentorial solitary fibrous tumour: Case report and review of literature. Neurol Neurochir Pol 43(1):77-82, 2009

6. Hori E, Kurimoto M, Fukuda O, Takahashi C, Nagai S, Oya T, Endo S: Recurrent intracranial solitary fibrous tumor initially diagnosed as hemangiopericytoma. Brain Tumor Pathol 24(1): 31-34, 2007

7. Huaringa A J, Zetola N, Naro Manuel H: Solitary fibrous tumors of the pleura: Report of eight cases and literature review. Internet Journal of Pulmonary Medicine 6(1), 2006

8. Lath R, Ranjan A, Gowrishankar S: Solitary fibrous tumor of meninges. Neurol India 53:248-249, 2005

9. Lee JM: Meningeal solitary fibrous tumor. J. Korean Neurosurg Soc 37(3):232-234, 2005

10. Macfarlane RG, Galloway M, Plowman PN, Thomas DG: A highly vascular intracranial solitary fibrous tumor treated with radiotherapy and toremifene: case report. Neurosurgery 56(6):1378, 2005

11. Miyashita K, Hayashi Y, Fujisawa H, Hasegawa M, Yamashita $\mathrm{J}$ : Recurrent intracranial solitary fibrous tumor with cerebrospinal fluid dissemination. Case report. J Neurosurg 101(6):1045-1048, 2004

12. Nakahara K, Yamada M, Shimizu S, Fujii K: Stereotactic Radiosurgery as adjuvant treatment for residual solitary fibrous tumor. Case Report. J Neurosurg 105(5):775-776, 2006

13. Ogawa K, Tada T, Takahashi S, Sugiyama N, Inaguma S, Takahashi SS, Shirai T: Malignant solitary fibrous tumor of the meninges. Virchows Arch 444(5):459-464, 2004

14. Paulus W, Scheithauer BW, Perry A: Mesenchymal nonmeningothelial tumours. In: David N. Louis, Hiroko Ohgaki, Otmar D. Weistler, Webster K. Cavenee, (eds), WHO Classification of Tumours of the Central Nervous System. Lyon: 2007:174
15. Pérez - Núňez A, Rivas JJ, Ricoy JR, Miranda P, Arrese I, Lobato $\mathrm{RD}$, Ramos A: Solitary fibrous tumor of the tentorium cerebelli. Case report. J. Neurosurg Sci 48(2): 59-62, 2004

16. Ritz R, Roser F, Bornemann A, Merkle $M$, Freudenstein D: Recurrence and increased proliferation rate of a solitary fibrous tumor in the central nervous system- case report and review of literature. Clin Neuropathol 24(6):252-256, 2005

17. Rodriguez F, Scheithauer BW, Ockner DM, Giannini C: Solitary fibrous tumor of the cerebellopontine angle with salivary gland heterotopia: A unique presentation. Am J Surg Pathol 28(1):139-142, 2004

18. Surendrababu NR, Chacko G, Daniel RT, Chacko AG: Solitary fibrous tumor of the lateral ventricle - CT appearances and pathologic correlation with follow-up. AJNR 27:2135-2136, 2006

19. Suzuki SO, Fukui M, Nishio S, Iwaki T: Clinicopathological features of solitary fibrous tumor of the meninges: An immunohistochemical reappraisal of cases previously diagnosed to be fibrous meningioma or hemangiopericytoma. Pathol Int 50(10): 808-817, 2000

20. Teranishi K, Yamamoto T, Nakao Y, Osada H, Wada R, Mori $\mathrm{K}$ : Recurrent solitary fibrous tumor of the falx cerebri with intraventricular extension. Neurol Med Chir (Tokyo) 47(6): 269-272, 2007

21. Tihan $T$, Viglione $M$, Rosenblum MK, Olivi A, Burger PC: Solitary fibrous tumors in the central nervous system- $A$ clinicopathologic review of 18 cases and comparison to meningeal hemangiopericytomas. Arch Pathol Lab Med 127(4): 432-439, 2003

22. Weon YC, Kim EY, Byun HS, Park K, Kim JH: Intracranial solitary fibrous tumors: Imaging findings in 6 consecutive patients. JNR 28:1466-1469, 2007

23. Yin W, Ma C, Wu J, Cai B, You C: A primary atypical solitary fibrous tumor of the sella mimicking non functional pituitary adenoma: A case report. Acta Neurochir (Wien) 152(3): 519-522, 2010 